\title{
PEMBUATAN PUPUK ORGANIK BERBAHAN ECENG GONDOK (Eichhornia Crassipes) MENGGUNAKAN ALAT PENCACAH LIMBAH ORGANIK
}

\author{
Moh Sarif Ismail ${ }^{1)}$, Iqrima Sstaddal ${ }^{2)}$, Sjahril Botutihe ${ }^{3)}$ \\ ${ }^{1}$ Mahasiswa Program Studi Mesin dan Peralatan Pertanian, Politeknik Gorontalo \\ ${ }^{2,3}$ Dosen Program Studi Mesin dan Peralatan Pertanian, Politeknik Gorontalo \\ Email: mohsarif.ismail@gmail.com
}

\begin{abstract}
ABSTRAK
Eceng Gondok (Eichhornia crassipes) merupakan jenis tanaman air yang mampu beradaptasi sehingga cepat berkembang biak pada lingkungan baru. Hal ini yang membuat eceng gondok menjadi gulma dominan diwilayah perairan yang tumbuh terapung dapat menggangu jalanya tranportasi perairan. Pemanfaatan Eceng Gondok salah satu yaitu sebagai pupuk organik yang berupa cair atau padat yang berguna terhadap unsur tanaman. Pupuk organik cair ataupun padat mengandung zat-zat serta unsur-unsur yang di butuhkan oleh tanaman. Tujuan penelitian adalah untuk mengetahui hasil ukuran hasil cacahan menggunakan mesin pencacah eceng gondok dengan daya putaran kecepatan 1420rpm, proses penyimpanan pengukuran suhu , dan hasil pupuk organik eceng gondok berupa pupuk padat dan cairan. Penelitian dilaksanakan di Laboratorium umum Mesin Peralatan Pertanian Politeknik Gorontalo. Penelitian pembuatan pupuk organik berbahan eceng metode pengujian di lakukan sebanyak 5 kali perlakuan. Hasil penelitian bahwa menunjukan bahwa Semakin kecil ukuran fraksi organik dari eceng gondok maka proses pengurain semakin cepat dan berbanding lurus dengan fase kematangan pupuk. Pada proses pencacahan eceng gondok didapatkan bahwa rata- rata ukuran hasil cacahan adalah $1,5 \mathrm{~cm}$ dengan ukuran yang paling kecil adalah $1 \mathrm{~cm}$.
\end{abstract}

Kata Kunci: Pupuk organik cair atau padat, eceng gondok, Hasil Penyimpanan

\section{ABSTRACT}

Water hyacinth (Eichhornia crassipes) is a type of aquatic plant that is who able to adapt so that it develops quickly Multiply on new environment.This thing which is make water hyacinth become wedds dominant in the territorial waters that grows floating can interfere the way transportation water. The Use of water hyacinth one of those is as organic Fertilizer in the from of liquid or solid that use full to plant elements. Liquid organic fertilizer or event solid contains subtances and the elemets needed by plants. Resear ch purposes is for knowing the results of the measurement measure using a calculator water hyacinth with rotatial power speed of 1420 rpm, process storage proces temperature measurenment, and organic fertilizer water hyacinth in the from solid fertilizer and Liquid. Research carrired out in the Laboratorary general machine agricultural equiment Gorontalo Polytechnic. Research making organic fertilizer made from water hyacinth testing method in done 5 times treatment.Research result that shows the smaller the size organic fraction from water hyacinth then the decomposition process the faster and di rectly protional and di rectly proportional with the maturity phase of the fertilizer in the enumeration process water hyacinth get that on average measure of chopped results is 1,5 $\mathrm{cm}$ with a size the smallest is $1 \mathrm{~cm}$.

Keywords : Liquid organic fertilizer or solid,wate hyacinth storage Results

e-ISSN 2503-2992

p-ISSN 2502-485X

Volume 5, Nomor 2, Novemberr 2020 


\section{PENDAHULUAN}

Eceng Gondok (Eichhornia crassipes) merupakan tanaman gulma di air. Tanaman ini sangat mudah beranak-pinak. Eceng Gondok tumbuh di sungai maupun rawa. Tangkai daun eceng gondok lunak. Tinggi tanaman tidak lebih dari $50 \mathrm{~cm}$. Eceng Gondok dapat hidup di dataran rendah maupun tinggi, daun berwarna hijau dan tampak seperti hanya mekar setengah. Tanaman ini mempunyai beberapa helai daun, bunganya berwarna ungu indah. Akar eceng gondok berbentuk serabut yang akan menangkap tanah yang ada di dalam air. Seluruh bagian Eceng Gondok dapat digunakan sebagai bahan baku pembuatan pupuk organik. Pupuk organik cair adalah pupuk yang kandungan bahan kimianya dapat memberikan hara yang sesuai dengan kebutuhan tanaman pada tanah. Pupuk organik padat adalah pupuk organik secara fisik bentuknya padat dengan kandungan yang sama pada pupuk cair (Taufika,2011).

Danau Limboto termasuk danau tipe rawa yang terletak di Kabupaten dan Kota Gorontalo, Provinsi Gorontalo pada posisi: 0 031 '58' 0 34'50" Lintang Utara dan 122 $57^{\prime} 40^{\prime \prime}$ $123^{\circ} 02^{\prime} 14$ " Bujur Timur.Kondisi lingkungan Danau Limboto semakin hari, cenderung semakin menurun. Permasalahan yang dihadapi di danau tersebut adalah sedimentasi yang tinggi dengan laju $1,5 \mathrm{~cm}$ per tahun dan eutrofikasi yang ditandai oleh pertumbuhan rumput liar dan eceng gondok (Eichhornia crassipes) yang telah mencapai luas $9.420 \mathrm{~m}$. Luas danau pada tahun 1932 adalah sekitar 8.000 ha, pada tahun 1970 menurun menjadi 4.500 ha. Pada tahun 1993 luas perairan ini berkurang menjadi 3.057 ha dengan kedalaman maksimum 2,3 $\mathrm{m}$, dan pada tahun 2004 luasnya tersisa 3.000 ha.

Saat ini, populasi tumbuhan Eceng Gondok di Danau limboto diperkirakan menutupi sekitar 70\% dari luas permukaan danau. Populasi tanaman ini di Danau Limboto mengalami perkembangan yang cukup pesat.

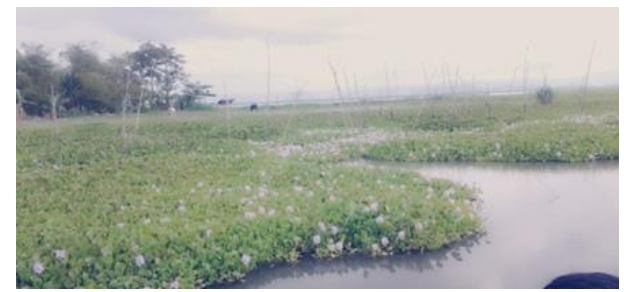

Gambar 1 Tanaman Eceng Gondok di Danau Limboto. (www.wikipedia, 2019)
Untuk mengatasi hal tersebut perlu dilakukan pengolahan, misalnya dengan cara pencacahan. Teknologi tepat guna adalah sebuah teknologi yang ditemukan atau diciptakan dengan tujuan untuk semakin meningkatkan atau membuat pekerjaan manusia menjadi lancar (Munaf, et al, 2008). Teknologi tersebut dibuat dengan tepat sesuai dengan kebutuhan manusia Pencacahan diperlukan untuk memperkecil ukuran eceng gondok sehingga memudahkan dalam pembuatan produk-produk olahan eceng gondok. Alat pencacah yang telah dibuat kebanyakan menggunakan pisau pemotong untuk mencacah bahan Eceng Gondok (Widayanto,2012).

Secara umum cara kerja dari alat pencacah Eceng Gondok yang telah ada adalah dengan memutarkan pisau pemotong yang terdapat pada tabung pemotongan untuk mencacah Eceng Gondok. Alat pencacah untuk membuat pupuk organik merupakan sebuah alat yang berfungsi sebagai penghancur bahan organik seperti dedaunan, rumput-rumputan dan sisa-sisa hasil pertanian dengan cara mencacahnya sampai dengan ukuran kecil-kecil berkisar $2-3 \mathrm{~cm}$. Selama ini sisa-sisa hasil pertanian tidak pernah dimanfaatkan dengan baik sehingga hanya menjadi limbah tanpa adanya nilai guna tambahan.

Proses pembuatan Eceng Gondok bisa berlangsung selama 10 hari bahkan lebih tergantung dari hasil cacahan Eceng Gondok, semakin cepat Eceng Gondok terurai maka proses menjadi pupuk organik akan semakin cepat juga. Dalam hal ini penelitian bertujuan untuk melihat seberapa cepat Eceng Gondok dapat menjadi pupuk organik berdasarkan hasil cacahan dan alat pencacah limbah organik.Oleh karena itu berdasarkan uraian-uraian diatas peneliti tertarik untuk melakukan penelitian tentang "Pembuatan Pupuk Organik Berbahan Eceng Gondok (Eichornia Crassipes) Menggunakan Alat Pencacah Limbah Organik".

\section{METODE PENELITIAN}

\section{Waktu Dan Tempat Penelitian}

Penelitian ini dilaksanakan pada bulan Mei - Agustus 2020 bertempat di laboratorium umum Teknik Mesin Dan Peralatan Pertanian Politeknik Gorontalo. 
Diagram Alir

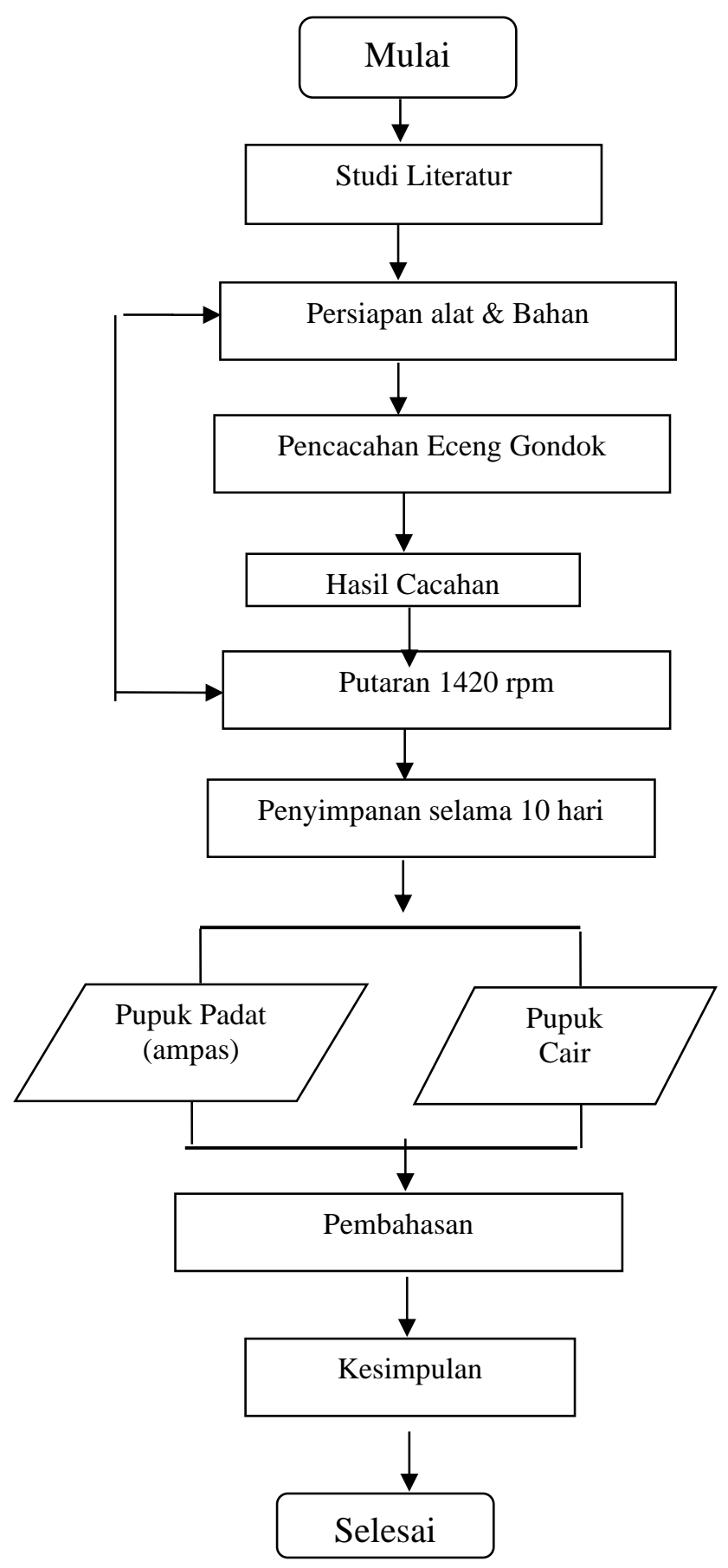

Gambar 2 Diagram Alir Penelitian

Dalam susunan diagram alir ada beberapa tahap yang perlu kita ketahui proses penelitian fabrikasi dan pengujian alat tugal pupuk. Yaitu dengan mengetahui skema pengujian bahan yang akan di tabur dengan kapasitas alat penabur.

\begin{abstract}
Alat
Alat yang digunakan dalam penelitian ini yaitu alat pencacah Eceng Gondok, wadah komposter, $\mathrm{pH}$ meter, termometer dan timbangan.
\end{abstract}

\section{Bahan}

Bahan yang digunakan dalam penelitian yaitu Eceng Gondok $3 \mathrm{~kg}$, air 2 liter, dan $3 \mathrm{ml}$ cairan EM4 dan gula merah.

\section{Proses Pembuatan pupuk Eceng Gondok}

- $\quad$ Menyediakan bahan yang akan di gunakan antara lain Eceng Gondok sebanyak $3 \mathrm{~kg}$, cairan EM4 sebanyak $3 \mathrm{ml}$ dan air 2 liter.

- Kemudian dimasukkan kedalam wadah komposter selanjutnya, hasil cacahan tersebut dicampurkan dengan air, dan EM4 selanjunya di aduk hingga merata

- Ditutup dengan rapat agar proses peembuatan pupuk berlangsung dengan baik.

\section{Penyimpanan Hasil Cacahan}

- Proses penyimpanan hasil cacahan disimpan pada wadah yang kering dan bersih, lalu disimpan pada ruangan yang bersuhu stabil. Selanjutnya tunggu hingga 7-10 hari. untuk mengecek tingkat kematangan.

- $\quad$ Lakukan proses pembalikan pada Eceng Gondok setiap hari, setelah itu melakukan pengukuran suhu yang dilakukan setiap hari.

\section{Hasil Penyimpanan Pupuk organik}

- Pengolahan hasil penyimpanan dilakukan dengan cara memisahkan antara pupuk cair dan pupuk padat (ampas).

- Pemisahan dilakukan pada ketiga perlakuan berdasarkan putaran dari mesin pencacah limbah organik.

- Hasil pemisahan selanjutnya di timbang dan diukur untuk mendapatkan berat pupuk cair dan pupuk padat (ampas).

\section{HASIL DAN PEMBAHASAN}

\section{Hasil Cacahan Eceng Gondok}

Pada proses pencacahan Eceng Gondok dilakukan dengan mesin alat pencacah yang telah dimodifikasi pada motor mesin. Pencacahan dilakukan sebanyak lima perlakuan dan 
menggunakan daya putaran sebesar $1.420 \mathrm{rpm}$. Hasil pencacahan Eceng Gondok terlihat pada Tabel 1

\begin{tabular}{ccccc} 
Perlakuan & Waktu & $\begin{array}{l}\text { Putaran } \\
(\text { menit })\end{array}$ & \multicolumn{2}{c}{ Hasil cacahan } \\
\cline { 4 - 5 } & & $\begin{array}{l}\text { Berat } \\
\text { (kg) }\end{array}$ & $\begin{array}{l}\text { Ukuran } \\
\text { (cm) }\end{array}$ \\
\hline 1 & 5 & & 0,5 & 1.2 \\
$\mathbf{2}$ & 10 & & 1,2 & 1.3 \\
$\mathbf{3}$ & 15 & 1420 & 1,5 & 1.5 \\
$\mathbf{4}$ & 20 & & 1,7 & 1.7 \\
$\mathbf{5}$ & 25 & & 2,2 & 2 \\
\hline
\end{tabular}

Sumber: Data Olah (2020)

BerdasarkanTabel 1 Proses pencacahan dilakukan selama 5 menit dan didapatkan hasil cacahan dengan ukuran sekitar $1.2 \mathrm{~cm}$ sedangkan pada percobaan kedua, ketiga, ke empat dan kelima masing-masing ukuran cacahan adalah 1.3, 1.5, 1.7 dan $2 \mathrm{~cm}$.

Variasi ukuran cacahan yang diperolehpada perlakuan 1 sampai 5 yaitu $1.2 \mathrm{~cm}$ yang mana ukuran ini dianggap masih belum terlalu halus untuk proses pembuatan pupuk organik. Ukuran cacahan yang halus dapat mempercepat laju pengomposan sehingga perlakuan mengalami proses penguraian dan dekomposisi selulosa dan lignoselulosa.

Semakin kecil ukuran cacahan maka semakin cepat proses pengomposan karena permukaan bahan baku akan bertambah dan memperudah smikroorganisme melakukan penguraian atau dekomposisi. Bahan organik yang memiliki ukuran yang besar sebaiknya dicacah terlebih dahulu namun pencacahan harus disesuaikan berdasarkan bahan organik tersebut. Bahan organik yang memiliki struktur yang keras sebaiknya di cacah dengan ukuran $0,5-1 \mathrm{~cm}$ namun bahan organik yang memiliki struktur yang lembek tidak perlu dicacah sangat kecil karena bahan yang sangat hancur akan mengandung banyak air atau memilki kelebaban yang sangat tinggi.2.Rasio $\mathrm{C} / \mathrm{NKondisi}$ kelengasan dan bahan dasar kompos menentukan nisbah $\mathrm{C} / \mathrm{N}$ dan nilai pupuk kompos. Hasil akhir kompos hara mengandung antara $30-60 \%$ bahan organic. Pengujian kimiawi termasuk pengkuran $\mathrm{C}, \mathrm{N}$, dan nisbah $\mathrm{C} / \mathrm{N}$ merupakanindikator kematangan kompos. Apabila nisbah $\mathrm{C} / \mathrm{N}$ kompos 20 atau lebih kecil berarti kompos tersebut siap digunakan. Akan tetapi, nisbah $\mathrm{C} / \mathrm{N}$ bahan kompos yang baik dapat berkisar antara 5 dan 20 (Sutanto, 2002).

Hal ini menunjukkan bahwa Semakin kecil ukuran cacahan fraksi/bahan organik maka proses pengomposan akan semakin cepat dan kualitasnya baik karena akan mempercepat pupuk untuk terurai. Selain itu hasil ukuran pada setiap menit memperlihatkan bahwa pada perlakuan 5 menit pertama didapatkan hasil ukuran yang lebih kecil dibanding dengan hasil cacahan pada perlakuan 5 yaitu 25 menit.

Hal ini dikarenakan jumlah Eceng Gondok yang dimasukkan pada perlakuan pertama lebih sedikit dibandingkan pada perlakuan 5 , sehingga proses ini dapat terangkan Eceng Gondok akan tercacah dengan baik apabila dimasukkan dengan jumlah yang sedikit.

\section{Hasil Penyimpanan Eceng Gondok}

PenyimpananEceng Gondok dilakukan selama 10 hari dengan mengukur suhu pada setiap perlakuan.Pengukuran suhu dilakukan untuk mendapatkan suhu maksimum dalam pembuatan Eceng Gondok.

Berdasarkan Tabel 2 didapatkan hasil pengukuran suhu yang berbeda-beda. Pada perlakuan 1 didapatkan suhu minimum yaitu $24 \mathrm{oC}$ dan suhu maksimum adalah 25.6 oC. Pada perlakuan 2 didapatkan suhu maksimum.Pada perlakuan 2 di dapatkan suhu minimum yaitu $26 \mathrm{oC}$ dan maksimum adalah $24,9^{\circ}$ C.Pada perlakuan 3 di dapatkan suhu minimum $25,4^{\circ} \mathrm{C}$ dan suhu maksimum adalah $25^{\circ}$ C. Pada perlakuan 4 di dapatkan suhu minimum $25^{\circ}$ $\mathrm{C}$ dan suhu maksimum adalah $24^{\circ} \mathrm{C}$. Pada perlakuan 5 di dapatkan suhu minimum yaitu $26{ }^{\circ} \mathrm{C}$ dan maksimum $26^{\circ} \mathrm{C}$. Dari 5 perlakuan didapatkan bahwa rata-rata suhu yang didapatkan yaitu $25^{\circ} \mathrm{C}$. Suhu pada proses penyimpanan terlalu rendah untuk proses dekomposisi, sebagaimana pada penelitian Diza dkk (2017), yang menyatakan bahwa proses pengomposan yang dilakukan oleh mikroba dapat bekerja secara optimal pada suhu $38-45^{\circ} \mathrm{C}$ selama beberapa minggu tergantung jumlah bahan yang digunakan

Tabel 2 Proses PenyimpananHasil Cacahan Eceng Gondok 


\begin{tabular}{|c|c|c|c|c|c|c|c|c|c|c|c|}
\hline \multirow{3}{*}{$\begin{array}{c}\text { Perlak } \\
\text { uan }\end{array}$} & \multicolumn{10}{|c|}{ Suhu Pada Hari ( ${ }^{0} \mathrm{C}$ ) } & \multirow{3}{*}{$\begin{array}{r}\text { Rata- } \\
\text { rata }\end{array}$} \\
\hline & \multirow[b]{2}{*}{1} & \multirow[b]{2}{*}{2} & \multirow[b]{2}{*}{3} & \multirow[b]{2}{*}{4} & \multirow[b]{2}{*}{5} & \multirow[b]{2}{*}{6} & \multirow[b]{2}{*}{7} & \multirow[b]{2}{*}{8} & \multirow[b]{2}{*}{9} & \multirow[b]{2}{*}{10} & \\
\hline & & & & & & & & & & & \\
\hline 1 & 25 & 24,3 & 24 & 25 & 25,6 & 24,5 & 24,2 & 24,3 & 24,7 & 24 & 24,56 \\
\hline 2 & 26 & 24 & 25,5 & 24 & 24,9 & 24 & 26 & 25 & 25,6 & 26 & 25,1 \\
\hline 3 & 24 & 24,5 & 24,3 & 25,5 & 25 & 25,3 & 25,5 & 24,7 & 25 & 25,4 & 24,94 \\
\hline 4 & 25,5 & 24,7 & 25 & 25,3 & 24 & 26,5 & 24,9 & 25,2 & 26 & 25 & 25,21 \\
\hline 5 & 25,2 & 25 & 25,6 & 25,9 & 26 & 26,9 & 26,3 & 24 & 25,9 & 26 & 25,28 \\
\hline
\end{tabular}

Sumber: Data Olah , (2020)

Tabel 3 Hasil Penyimpanan Pupuk

\begin{tabular}{|c|c|c|c|c|c|}
\hline Ukuran & \multirow{2}{*}{$\begin{array}{c}\text { Hasil } \\
\text { Cacahan } \\
(\mathrm{Kg})\end{array}$} & \multirow{2}{*}{$\begin{array}{l}\text { Volume } \\
\text { Em4 } \\
\text { (ml) }\end{array}$} & \multirow{2}{*}{$\begin{array}{l}\text { Gula merah } \\
\text { cair (ml) }\end{array}$} & \multicolumn{2}{|c|}{ Pupuk yang dihasilkan } \\
\hline $\begin{array}{l}\text { Eceng } \\
\text { Gondok }\end{array}$ & & & & Padat (gr) & Cair (ml) \\
\hline Hasil & & & & & \\
\hline \multirow{2}{*}{\multicolumn{6}{|c|}{$\begin{array}{c}\text { Cacahan } \\
(\mathrm{cm})\end{array}$}} \\
\hline & & & & & \\
\hline 1.2 & 0.5 & 40 & 110 & 220 & 600 \\
\hline 1.3 & 1.2 & 40 & 110 & 600 & 1,200 \\
\hline 1.5 & 1.5 & 40 & 100 & 960 & 1,450 \\
\hline 1.7 & 1.7 & 40 & 110 & 1.100 & 1,700 \\
\hline 2.0 & 2.2 & 40 & 110 & 1.300 & 2,100 \\
\hline
\end{tabular}

\section{Hasil Penyimpanan Pupuk Eceng Gondok}

Penyimpanan Eceng Gondok dilakukan selama 10 hari dengan menghasilkan pupuk padatan dan pupuk cairan. Pupuk padatan merupakan hasil dari cacahan Eceng Gondok sedangkan pupuk cair ada hasil pengomposan Eceng Gondok dan larutan EM4 selama proses penyimpanan. Hasil penyimpanan pupuk tersaji pada tabel 3 .

Berdasarkan Tabel 4.3 hasil penelitian menunjukkan bahwa pengulangan pertama dengan ukuran $1 \mathrm{~cm}$ menghasilkan pupuk organik cair dan padat masing-masing $600 \mathrm{ml}$ dan 220 gr merupakan hasil paling sedikit dari semua pengulangan.Hal ini dikarenakan hasil cacahan 1,2 $\mathrm{cm}$ adalahyang paling bagus dari semua cacahan yang didapatkan.semakin kecil ukuran fraksi organik dari Eceng Gondok maka proses penguraian semakin cepat yang berbanding lurus dengan fase kematangan pupuk.

\section{Kesimpulan}

- Hasil cacahan eceng gondok menggunakan mesin Pencacah dengan putaran $1420 \mathrm{rpm}$ memiliki ukuran yang berbeda-beda,yakni $1.2 \mathrm{~cm}$ sampai dengan $2 \mathrm{~cm}$. 
- Pada proses penyimpanan cacahan eceng gondok dalam pembuatan pupuk,suhu yang dihasilkan bervariasi dari hari ke-1 sampai ke-10.Suhu minimum dan maksimum yang diperoleh selama penyimpanan masing-masing $24^{\circ} \mathrm{C}$ dan $26^{\circ} \mathrm{C}$ yang hara suhu ini belum memenuhi syarat untuk proses dekomposisi

- Hasil Cacahan pupuk cair dan padat masingmasing $600 \mathrm{ml}$ dan 220 gr merupakan hasil paling sedikit dari semua pengulangan.sedangkan yang paling banyak masing-masing $1,300 \mathrm{ml}$ dan 2,100 gr.

\section{DAFTAR PUSTAKA}

Agneesia.Kristiyani.M. 2009.Pembuatan Kompos Eceng Gondok (Eichhornia crassipes (Mart) Solms.) dengan Penambahan Bioaktivator yang Berbeda dan Uji Kualitas Kompos pada Pertumbuhan Tanaman Cabai Merah (Capsicum annuum L.)(Skripsi).Program Studi Sarjana Biologi, Universitas Hassanudin. Makassar.

Antu, E., Djamalu, Y. (2018). Desain Mesin Pencacah Sampah Organik Rumah Tangga Untuk Pembuatan Pupuk Kompos. Jurnal Teknologi Pertanian Gorontalo (JTPG), 3(2), 57-65.

Antu, E., Sunge, R., \&Djafar, R., 2019. Rancang Bangun Dan Pengujian Alat Pencacah Kompos Dengan Sudut Mata Pisau 45o. Jurnal Teknologi Pertanian Gorontalo (JTPG), 4(2), 62-70.

Anonim. 2020. Manfaat Eceng Gondok Untuk Pupuk. Tanggal Akses : 2 januari 2020. Link :https://bertanidi.blogspot.com/2014/07/manfaatenceng-gondok-untuk-pupuk.html. : https://id.wikipedia.org/wiki/Eceng gondok.

Diza K Vandra, Zulhelmi, Syaryadhi Mohd. 2017. Monitoring Suhu dan Kelembaban Menggunakan Mikrokontroler ATMega328 pada Proses Dekomposisi Pupuk Kompos. Jurnal KITEKRO: Online Teknik Elektro.Vol.2 No.3 2017. Hal 91-98.
Deno Okalia, Tri Nopsagiarti,Chairil Ezward. 2018. Pengaruh ukuran cacahan tandan kosong kelapasawit terhadap karakteristik fisik kompos tritankos(triko tandan kosong)Jurnal AgroquaVol. 16 No. 2.

Hajama,Nursyakia.2014.Studi Pemanfaatan Eceng Gondok Sebagai Bahan Pembuatan Pupuk Kompos Dengan Menggunakan Aktivator EM4 dan Mol Serta Prospek Pengembangannya.(Skripsi).

Makassar: Fakultas Teknik Universitas Hasanuddin.

Munaf Dicky R., Suseno Thomas, Janu Rizaldi Indra, M. Badar Aulia. 2008. "Peran Teknologi Tepat Guna untuk Masyarakat Daerah Perbatasan" (Propinsi Kepulauan Riau).

Noviyanti, F., Syarifah., Hidayah, N. 2016. Pengaruh Pemberian Pupuk Organik Cair Daun Gamal(Gliricidia sepium (Jacq.) Kunth ex Walp.)Terhadap Pertumbuhan Tanaman Sawi. Jurnal BiotaVol. 2 No. 1

R. D. Ratnani, I. Hartati, L. Kurniasari. 2011. Pemanfaatan Eceng Gondok (Eichornia Crassipes) Untuk Menurunkan Kandungan Cod (Chemical Oxygen Demond), Ph, Bau, Dan Warna Pada Limbah Cair . Jurnal Ilmiah Momentum Vol 7 No 1.

Sutanto, $\quad$ R. 2002.

PenerapanPertanianOrganik.Kanisiu s. Yogyakarta.

Taufika, R.

2011.PengujianBeberapaDosisPupu

kOrganikCairTerhadapPertumbuha ndanHasilTanamanWortel

(Doucuscarota

L).JurnalTanamanHortikultura.Mei-

Agustus.

Widayanto Jujur S. 2012. Rancang Bangun Mesin Pencacah Enceng Gondok untuk Pembuatan Biogas. Tugas Akhir Mahasiswa Diploma III, Jurusan Teknik 
Mesin:FakultasTeknik UNDIP, Semarang.

Sutanto, Rachman. 2002. Penerapan Pertanian

Organik. Kanisius. Yogyakarta 